\title{
Genetic Evolution of Infectious Bursal Disease Virus Isolated from Chicken Poultry Flocks in Egypt
}

\author{
Sabry E.Omar ${ }^{1}$, Walaa Abd El Moneim El Sayed ${ }^{2}$, Ahmed Abdelhalim³ ${ }^{3}$ and Nahed Yehia ${ }^{3 *}$ \\ ${ }^{1}$ Poultry Diseases Department, Benha Provincial Laboratory, Animal Health Research Institute, Agriculture Research Canter, Benha, Egypt \\ ${ }^{2}$ Newcastle Department Veterinary Serum and Vaccine Research Institute, Agriculture Research Canter, Cairo, Egypt \\ ${ }^{3}$ Reference Laboratory for Veterinary Quality Control on Poultry Production, Animal Health Research Institute, Agriculture Research Canter, \\ Giza 12618, Egypt
}

*Corresponding author’s Email: nahedyehia @ gmail.com; ORCID: 0000-0002-2823-6467

Received: 18 Mar. 2021

Accepted: 29 Apr. 2021

\begin{abstract}
Infectious Bursal Disease Virus (IBDV) is highly infectious and causes severe economic losses in the Egyptian poultry industry. In the present study, 40 samples of bursa Fabricius tissue were collected from various poultry flocks residing in six governorates during 2020 in Egypt (8 from El-Daqhlia, 10 from El-Sharquia, 10 from El-Qaliobiyea, 4 from EL-Behera, 6 from Alexandria, and 2 from El-Gharbia). Among these flocks, the chicken suffered from depression, dehydration, and ruffled feather with high mortality rates (20-50\%) leading to the haemorrhagic and enlarged bursa of Fabricius. Reverse transcription-polymerase chain reaction (RT-PCR) was performed, targeting the hypervariable region of the VP2 gene of IBDV. The 30 samples were detected positive by RT-PCR (8 from ElDaqhlia, 7 from El-Sharquia, 6 from El-Qaliobiyea, 3 from EL-Behera, 5 from Alexandria, and 1 broiler chicken from El-Gharbia). A total of 10 strains were selected for genetic analysis, representing different governorates. All identified strains belonged to a very virulent IBDV with 95.7-96.7\% nucleotide identity and 98.2-99.4\% amino acid identity with very virulent IBDV strains from Europe and Asia. Phylogenetically, the Egyptian strain was divided into two subgroups. All strains identified in the present study belonged to the phylogenetic subgroup I with new eight nucleotide mutation mutations when compared with HK64 and other Egyptian strains. All sequenced viruses had G254S mutation. Moreover, Y220F mutation was detected in major hydrophilic region A, in two strains (EGY/SN5 and EGY/SN10), compared with HK64. These mutations may increase viral pathogenicity and antigenicity. The Egyptian strains in the study were distinct from the vaccinal strain. Furthermore, they may explain the recent IBDV outbreaks reported in vaccinated flocks. The current study highlighted the importance of continuous monitoring of mutations in IBDV, and the assessment of their effects on virus virulence and vaccine efficacy against newly evolved strains.
\end{abstract}

Keywords: Genetic characterisation, Hypervariable region, Infectious bursal disease virus, VP2 gene

\section{INTRODUCTION}

Infectious bursal disease (IBD) is a highly infectious viral disease with high mortality rates in three to six-week-old chickens. The immune suppression caused by IBD infects active B-lymphocytes in the bursa of Fabricius leading to an increased susceptibility to secondary viral or bacterial infections (Banda and Villegas El-Attrache, 2003; Lukert and Saif, 2003). Infectious bursal disease virus was first detected in the USA in 1957, and in Egypt in 1974 (Cosgrove, 1962; El-Sergany et al., 1974).

Infectious bursal disease virus belongs to the Avibirnavirus genus of the family Birnaviridae. The genome comprises two segments of double-stranded RNA (A and B) (Murphy et al., 1999). Segment B encodes Viral
Protein 1(VP1), which is responsible for polymerase activity. Segment A includes two Open Reading Frames (ORF), the largest of which encodes a polyprotein, comprising VP2, VP3 and VP4. The Viral Protein 2 (VP2) contains the major antigenic site that is important in the induction of neutralizing antibodies. Early neutralizing antibodies are directed towards VP3 and VP4 offering the serine protease activity which cleaves the polyprotein into its various counterparts. The small ORF encodes VP5, a non-structural protein involved in induced bursal disease (Mundt et al., 1995; Lejal et al., 2000).

Viral Protein 2, which is important for the eliciting of a neutralizing antibody response, consists of three main domains, namely the base, shell and projection domains. 
The base and shell domains are conserved domains while the projection domain is formed by the hypervariable region at Amino Acids (AAs) 206-350 containing two hydrophilic regions, region A (212-224 A.A.) and region B (314 to 325 AA). Infectious bursal disease virus characterisation depends upon the Hypervariablre Region (HVR) region antigenicity. The amino acid sequence analysis revealed numerous pathogenic variants that can overcome the host immune response (Durairaj et al., 2011). Such variations responsible for high virulence and cellular tropism include 253 glutamine, 279 aspartic acids at AA position 279, and 284 alanine (Bayliss et al., 1990; Coulibaly et al., 2005; Letzel et al., 2007). Thus, in recent years, strain identification has been based upon a genetic variation of the VP2 gene (Bayliss et al., 1990; Brown et al., 1994).

Infectious bursal disease virus can be classified into two different IBDV serotypes. Serotype 1 is pathogenic to chickens while serotype 2 is believed to be nonpathogenic. Based on the antigenic variation and virulence, serotype 1 is divided into several groups (classical strains, variant strains and very virulent (vv) strains (Zierenberg et al., 2000). Classic IBDV strains cause up to $20-30 \%$ mortality rates due to lymphoid necrosis and bursal damage (Muller et al., 2003). The vv IBDV strains caused severe outbreaks with mortality rates of $60-70 \%$ in chickens in the mid-1980s, then they were transmitted to the Middle East, Africa, Asia, and South America (Murphy et al., 1999; Abdel-Alem et al., 2003). In Egypt, vv IBDV was recorded in 1989 (El-Batrawi AM and El-Kady, 1990).

Variant strains causing severe atrophy in the bursa and a reduced inflammatory response with high mortality rates even among vaccinated flocks that were first identified in the USA (Snyder et al., 1990). Variant strains were then recorded in many Egyptian flocks (El-Sonusi et al., 1994), and they spread rapidly through the poultry industry. Evidence of circulating variant IBDV strains was collected from flocks that were infected despite multiple vaccination strategies, causing severe economic losses (Hussein et al., 2003; Metwally et al., 2009).

Live IBDV vaccines are produced from fully or partially attenuated strains of the virus, known as mild, intermediate or intermediate plus vaccines. Intermediate or intermediate plus vaccines are used to protect broiler chickens and commercial layer flocks. Some of these vaccines are also used in young parent chickens if there is a high risk of natural infection with vv IBDV (Mahgoub, 2010).
Previously, diagnosis of IBD relied on the isolation of the virus and serological testing using Fluorescent Antibody Technique (FAT), Enzyme-Linked Immunosorbent Assay (ELISA), Agar Gel Precipitation Test (AGPT). However, IBDV can now be rapidly detected by Reverse Transcription-Polymerase Chain Reaction (RT-PCR) with high sensitivity and specificity (Van den Berg, 2000). Variation in the VP2 gene is commonly analysed, as its protein contains the major protective epitopes that are important for determining the pathogenicity (Abdel-Alem et al., 2003; Tomás et al., 2012).

The aim of the present study was to characterise the evolution of the VP2 gene in IBDV strains detected in layer and broiler chickens in Egypt during 2020.

\section{MATERIAL AND METHODS}

\section{Ethical approval}

Veterinarians collected Bursa of Fabricius samples from freshly dead chicken in commercial chicken farms without the need for anaesthetizing.

\section{Viral samples}

A total of 40 samples obtained from the bursa of Fabricius were collected from the freshly dead chickens from broiler and layer farms during 2020 in six governorates in Egypt. Sample collection took place by obtaining 8 samples from El-Daqhlia, 10 from ElSharquia, 10 from El-Qaliobiyea, 4 from EL-Behera, 6 from Alexandria, and 2 from El-Gharbia. The majority of chickens had been vaccinated with Bursa-vac (MERCK, USA) and CEVAC-IBD (CEVA, Egypt) (intermediate plus). The samples were collected and immediately transported to National Laboratory for veterinary Quality control on Poultry production (NLQP) in the icebox. The bursa samples were homogenated and processed according to Hirai and Shimakura (1974).

\section{Virus isolation}

The supernatant of the homogenized bursa was inoculated into 10-day-old Specific Pathogen Free (SPF) embryonated chicken eggs via the Chorioallantoic Membrane (CAM), and incubated at $37^{\circ} \mathrm{C}$ with daily candling. The eggs were collected 96 hours postinoculation (Hitchner, 1970). The Allantoic fluids were aseptically collected for testing by rapid slide haemagglutination test as reported by Wlliams (2016). 
Infectious bursal disease virus detection by the reverse transcription-polymerase chain reaction

RNA was extracted from the grinding Bursa using QiAmp Viral RNA Mini kit (Qiagen GmbH, Hilden, Germany) according to the manufacturer's instructions. The amplification of the VP2 gene by RT-PCR using Phusion ${ }^{\circledR}$ high fidelity DNA polymers (Thermo, MA, USA) and gene-specific primers according to the manufacturer's protocol. The gene-specific PCR amplicons were detected by agarose gel electrophoresis. The primer sequences used were as follows; AUS GU (forward): 5'-TCACCGTCCTCAGCTTACCCACATC-3', and AUS GL (reverse) 5'GGATTTGGGATCAGCTCGAAGTTG C-3'(Metwally et al., 2009).

\section{Sequence analysis of VP2 of infectious bursal disease virus}

A total of 10 cases representing different governorates in Egypt were randomly selected for sequence analysis, as shown in Table 1. Purification and sequencing of positive amplicons were carried out using the QIAquick Gel Extraction Kit (Qiagen, Hilden, Germany) and the BigDye Terminator v3.1 Cycle Sequencing Kit (Applied Biosystems, California, USA) using gene-specific primers. The nucleotide sequence was detected by the ABI 3500 Genetic Analyzer (Life Technologies, California, USA). All strains were published by the National Centre for Biotechnology Information (NCBI).

Table 1. Epidemiological data of selected sequencing strains of VP2 of infectious bursal disease virus in the chicken flock in Egypt during 2020

\begin{tabular}{|c|c|c|c|c|c|c|}
\hline Virus isolate & $\begin{array}{l}\text { Date of } \\
\text { collection }\end{array}$ & $\begin{array}{c}\text { Age of } \\
\text { chickens (day) }\end{array}$ & Breed & Governorates & Vaccines & $\begin{array}{c}\text { Genbank } \\
\text { accession number }\end{array}$ \\
\hline IBDV-Egy-SN1 & January 2020 & 20 & Layer & El-Daqhlia & Bursa-vac & MT992244 \\
\hline IBDV-Egy-SN2 & February 2020 & 25 & Layer & El-Sharquia & CEVAC IBD & MT992245 \\
\hline IBDV-Egy-SN3 & March 2020 & 35 & Broiler & Alexandria & No & МТ992246 \\
\hline IBDV-Egy-SN4 & January 2020 & 33 & Layer & El-Qaliobiyea & Bursa- vac & MT992247 \\
\hline IBDV-Egy-SN5 & June 2020 & 36 & Broiler & El-Gharbia & CEVAC IBD & MT992248 \\
\hline IBDV-Egy-SN6 & July 2020 & 33 & Broiler & EL-Behera & Bursa-vac & MT992249 \\
\hline IBDV-Egy-SN7 & April 2020 & 30 & Layer & El-Qaliobiyea & No & МТ992250 \\
\hline IBDV-Egy-SN8 & March 2020 & 25 & Layer & Alexandria & Bursa-vac & MT992251 \\
\hline IBDV-Egy-SN9 & March 2020 & 22 & Broiler & El-Sharquia & No & MT992252 \\
\hline IBDV-Egy-SN10 & June 2020 & 15 & Layer & El-Gharbia & Bursa-vac & MT992253 \\
\hline
\end{tabular}

IBDV: Infectious bursal disease virus

\section{Genetic and phylogenetic analysis}

Pairwise nucleotide percent identity was calculated using DNA STAR Lasergene software (MegAlign module, DNASTAR software; Lasergene version 7.2; DNASTAR, Madison, WI, USA). The nucleotide and amino acid sequences were aligned with 20 related strains obtained from GenBank (HK64 was used as a reference strain; specific strains were previously used to represent classical strains from the Netherlands, USA, France and Canada, vaccine strains and vvIBDV from China, India, Vietnam, Hong Kong, Korea, Germany, Pakistan, France and Egypt during 2004-2019) (Table 2) using MegAlign module of DNASTAR software (Lasergene version 7.2; DNASTAR, Madison, WI, USA, Mohamed et al, 2014). A Phylogenetic tree was constructed using MEGA software (version 7), employing a maximum likelihood tree method with moderate strength and 1000 bootstrap replicates (Kumar et al., 2016). The VP2 gene sequence of selected strains in this study published in the National Center for Biotechnology Information (NCBI) under accession number (Table 1).
Table 2. The data of the infectious bursal disease reference strains collected from Genbank and Phylogenetic tree (strain name, country, and accession number)

\begin{tabular}{llc}
\hline Strain & Country & Accession number \\
\hline Giza-2008 & Egypt & EU584433.2 \\
\hline BSU-03-2015 & Egypt & KX077978.1 \\
\hline SV-G4-2013 & Egypt & KC865603.1 \\
\hline S10-2013 & Egypt & KF444833.1 \\
\hline SD/JN08-2009 & China & FJ824672.1 \\
\hline VMB-Karnataka-India-2005 & India & EU788042.1 \\
\hline GHUT1-2016 & Vietnam & AY841901.1 \\
\hline HK46-2016 & Hong Kong & AF051838.1 \\
\hline SH-92-2004 & Korea & AF533670.1 \\
\hline K357-88-2016 & Germany & AF159216.1 \\
\hline UAF06-2016 & Pakistan & EF529700.1 \\
\hline Br/Kalubia -07-2018 & Egypt & MH078256.1 \\
\hline F52/70/2016 & France & Y14958 \\
\hline D78-2019 & Netherland & MH329180.1 \\
\hline Ahungary-903-78-2012 & USA & JQ411012.1 \\
\hline hungary-CEVACIBD-2016 & Franch & AJ632141.1 \\
\hline RANUSA-STC-2007 & Canda & D00499.1 \\
\hline Bursa-vac-2016 & USA & AF498633.1 \\
\hline
\end{tabular}




\section{RESULTS}

\section{Clinical signs}

The chickens were reported to represent the clinical signs of depression, diarrhoea, ruffled feathers and dehydration. There was also a high mortality rate among the chickens analysed in the present study ranged from $20-50 \%$. The $20 \%$ mortality was seen in 10 affected flocks and 50\% mortality was seen in 15 affected flocks and the other within the range.

\section{Gross pathology}

A post-mortem study of lesions from all chickens in the current study that had recently suffered fatality revealed severe haemorrhages on visceral organs, and the bursa of Fabricius which was also enlarged and oedematous. In 30 cases, yellowish gelatinous exudates and bursal atrophy were detected.

Infectious bursal disease virus isolation from the embryonated chicken eggs

The mortality rate of infected embryos varied from 0 to $100 \%$. Allotonic fluid was negative for the rapid HA test, and a haemorrhage on the CAM was observed. The dead embryo after three to seven days after inoculation exhibited dwarfing, cerebral oedema, congestion and haemorrhage of the feather. Furthermore, mottled necrosis and congestion on the liver, greenish colouration of the kidney, enlarged spleen and pale heart were noted in all dead embryos.

\section{results}

Reverse transcription-polymerase chain reaction

A total of 30 samples tested positive for IBDV by PCR (visualised as 630-bp band indicating the VP2 gene). These samples were collected from six governorates (five broilers/three layers from El-Daqhlia, four broilers/three layers from El-Sharquia, five broilers/one layer chicken from El-Qaliobiyea, two broilers/ one layer chicken from EL-Behera, three broiler/two layer chicken from Alexandria and one broiler chicken from El-Gharbia) (Table 3).

\section{Molecular characterisation of VP2 in infectious} bursal disease virus

Nucleotide phylogenetic analysis was used to compare the 10 selected isolates with strains identified in different countries between 2004 and 2019. The classical, vaccinal, vv IBDV, and other considered Egyptian strains are listed in Table 2. The results indicated that the Egyptian strains identified in the present study genetically clustered with vv European and Asian IBDV strains
(K357, SH-92 and HK46). The Egyptian strains are divided into two subgroups (I and II) as shown in Figure 1. The strains of samples in the current study clustered to subgroup I.

The nucleotide and amino acid identities of the 10 isolates were compared to European and Chinese strains, K357, SH-92, and HK46, with 95.7-96.7\% (98.2-99.4\% AA). With the vaccinal strains, D78, BURSA-VAC, and CEVAC-IBD, the Egyptian strains shared 92-92.8\% (9393.6\% AA), 92.8-93.6\% (93.6-94.2\% AA), and 92.693.4\% (95.3-95.9\% AA) of identity, respectively (Figures 2 and 3 ).

Comparing with the HK64 reference strain, all strains identified in the present study harboured specific mutations characteristic of vv IBDV (A222 in major hydrophilic region A, I242 and Q253 in minor hydrophilic region 1, I256, 270A, 294I, and 299S in minor hydrophilic region 3). However, neither L324 nor V321 were detected, which are also characteristic of vvIBDV. Mutation analysis of Egyptian strain in this study had new eight nucleotide mutations compared with HK64 and other Egyptian strains. They had G254S, which is found in all Egyptian strains cluster them in new subgroup I. In addition, EGY/SN5 and EGY/SN10 harboured Y220Fin major hydrophilic region A, as per other Egyptian strains. The 10 vvIBDV isolates under the study had the restriction site (Ssp1), due to the substitution of L294I which is not observed in the vaccine D78 (intermediate), Bursaac+, and CEVAC IBD (intermediate plus).

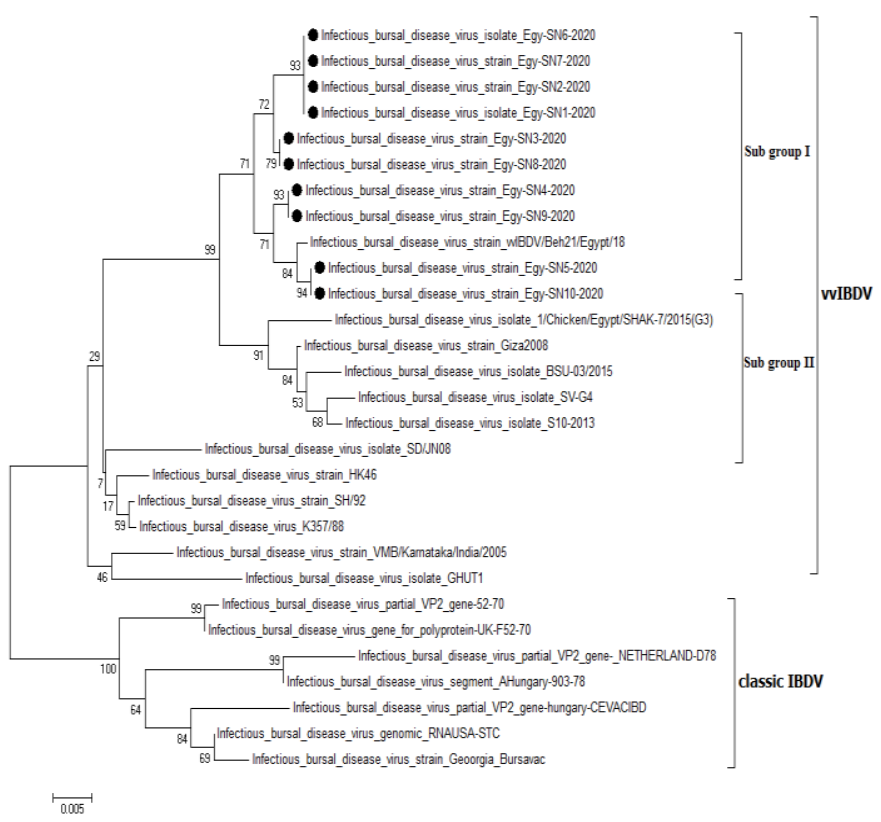

Figure 1. Nucleotide phylogenetic tree of the gene coding VP2 protein of infectious bursal disease virus 


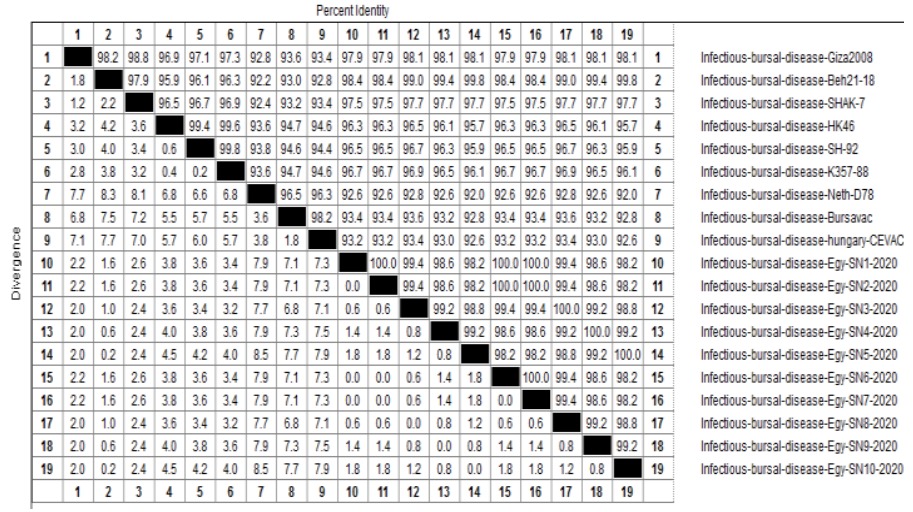

Figure 2. Nucleotide identities and divergence of Sequenced viruses, compared to other selected strains from European and Asian strains

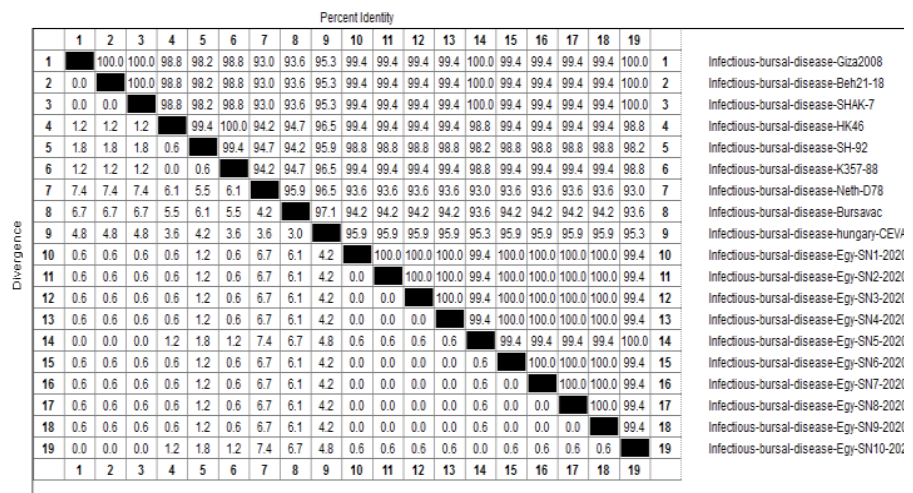

Figure 3. Amino acid identities and divergence of Sequenced viruses, compared to other selected strains from European and Asian strains

Table 3. The result of PCR in poultry flocks (Broiler and layer) in different governorates of Egypt in 2020

\begin{tabular}{lll}
\hline Governrates & $\begin{array}{l}\text { Tested flocks } \\
\text { (Number) }\end{array}$ & $\begin{array}{l}\text { Positive sample for } \\
\text { infectious bursal disease } \\
\text { (Number) }\end{array}$ \\
\hline El-Daqhlia & $8(5$ broilers/3 layers $)$ & 8 ( 5 broilers/3 layers $)$ \\
\hline El-Sharquia & $10(7$ broilers/3 layers) & 7 ( 4 broilers/3 layers $)$ \\
\hline El-Qaliobiyea & $10(8$ broilers/2 layers) & $6(5$ broilers/ 1 layer $)$ \\
\hline EL-Behera & $4(3$ broilers/1 layer $)$ & $3(2$ broilers/ 1 layer $)$ \\
\hline Alexandria & $6(3$ broilers/3 layers $)$ & $5(3$ broilers/2 layers $)$ \\
\hline El-Gharbia & $2(2$ broilers $)$ & 1 (broiler $)$ \\
\hline
\end{tabular}

\section{DISCUSSION}

Infectious bursal disease is among the most significant infectious immunosuppressive diseases of poultry (Dobos et al., 1979), increasing susceptibility to many infectious agents that are non-pathogenic in healthy chickens (Saif, 1991). The control of IBDV infections depends on vaccination, but IBDV strains have become resistant to some vaccines due to mutation and possible reassortment or recombination that increase viral pathogenicity and virulence (Jackwood et al., 2008; Jackwood and SommerWagner, 2011). In Egypt, IBD outbreaks have occurred in vaccinated chicken flocks leading to critical economic losses to the Egyptian poultry industry (Helal et al., 2012; Abd mawgod et al., 2014; Mohamed et al., 2014; Abou ElFetouh and Abdallah, 2018). The aim of the present study was to determine the prevalence of IBDV in Egypt in 2020 to detect the genetic variability of the HVR of VP2 gene and to investigate how this is related to the efficacy of vaccines currently used to control IBD outbreaks in Egypt.

The clinical diagnosis of IBD depends on the observation of symptoms and post mortem investigation of the bursa of Fabricius (Hassan, 2004; Rauw et al., 2007). The cases included in the current study indicated depression, diarrhoea, mortality, and gross lesions of the bursa of Fabricius such as haemorrhage, and oedema. It was suspected that the isolated strains were vv based on the pathogenicity, as it was more similar to that of characterised vv strains compared with mild strains (Van Den Berg, 2000).

The detection of the IBDV using RT-PCR is the sensitive test to detect IBDV infection in the chicken flocks (Abdel-Alem et al., 2003; Muller et al., 2003). In the present study, 30/40 field samples were positive for IBDV in Egypt and the majority of them were vaccinated, indicating an outbreak of IBDV in the vaccinated flocks, as previously recorded (Abd mawgod et al., 2014; Hagag et al., 2015; Abou El-Fetouh and Abdallah, 2018). The HVR of VP2 was sequenced to assess the pathogenicity and virulence of the isolated field strains. This can be used to classify IBDV strains into genogroups, as it is possible for other viruses of family birnaviridae (Letzel et al., 2007; Petkov et al., 2007). Phylogenetic analysis is used to classify IBDV into three main genogroups (classical, variant, and vv IBDV) (Van den Berg et al., 2004). All strains in the current study were related to vv IBDV strains, resembling previously recorded Egyptian strains (Abd mawgod et al., 2014; Hagag et al., 2015; Abou ElFetouh and Abdallah, 2018). The strains identified in the current study acquired new specific nucleotide mutations clustering them into new subgroup I.

In line with previous studies, the findings of the current study were indicative of the conserved markers of virulence (222A, 242I, 249Q, 253Q, 256I, 272I, 279D, 284A, 294I, and 299S) when compared with HK64 (Barathidasan et al., 2013; Patel et al., 2016; Michel and Jackwood, 2017). The 253Q mutation was also present, which played a significant role in cell tropism (Boot et al., 2000; Brandt et al., 2001; Qi et al., 2009). All isolates in this study harboured the G254S mutation that has been 
reported previously in Egypt (Hagag et al., 2015; Abou ElFetouh and Abdallah, 2018), Tanzania (Kasanga et al., 2007), Nigeria (Adamu et al., 2013; Nwagbo et al., 2016), and Ethiopia (Negash et al., 2012). The two strains (EGY/SN5 and EGY/SN10) identified in the present study harboured the Y220F mutation in major hydrophilic region A as previously recorded (Abd mawgod et al., 2014). The resulting amino acid replacement may affect virus antigenicity, and play an important role in raising the virulence in the presence of maternal antibodies (ElBagoury et al., 2018). The Egyptian strain in the current study had 8 nucleotide silent mutation when compared with HK64 which can be the initiation of new A.A mutation with a great effect on the virulence of the virus.

Egypt uses classical strains of intermediate and intermediate plus IBD vaccines that are commercially available. These have been previously shown to be protective against vv IBDV strains (van den Berg et al., 2004; Rautenschlein et al., 2005). However, intensive vaccine distribution has led to the emergence of highly virulent mutated strains that can cause IBD outbreaks in vaccinated flocks (Hagag et al., 2015; Alkie and Rautenschlein, 2016) in the current study, the Egyptian strain was distinct from vaccinal strains (D78, BURSAVAC, and CEVAC-IBD) as previously reported (Jackwood et al., 2008; Adamu et al., 2013; Sultan et al., 2015). Further studies are required to determine the effectiveness of commercial vaccines in immunising chickens against virulent field strains. It is suggested that effective protection against vv IBDV may be achieved in case vaccines are prepared based on autogenous strains causing current outbreaks.

\section{CONCLUSION}

Egyptian infectious bursal disease virus (IBDV) has evolved continuously. VP2 gene in strains of the current study clustered with very virulent IBDV from Europe and Asia with Amino Acid identity of 98.2 - 99.4\%. Phylogenetically, the Egyptian strains were divided into two subgroups with specific features. The strain in the present study was clustered to IBDV subgroup I. The strains harboured new mutations, which has likely arisen due to vaccination pressure, and which may increase the virulence of the virus. Therefore, there is a need for continuous monitoring of IBDV genetic variability in Egypt is required, as well as an analysis of the consequent effects on pathogenicity, antigenicity and vaccine efficacy against newly evolved strains.

\section{DECLARATIONS}

\section{Competing interests} interest.

The authors declare that they have no conflict of

Consent to publish

It was not applicable.

\section{Authors' contribution}

Sabry E.Omar, Walaa Abd El Moneim El Sayed was carried out Tissue specimen collection from the affected flocks, Ahmed Abd Elhalim Mohammed detected the DNA of infectious bursal disease virus and analyzed the data and writing the manuscript. Nahed Yehia carried out the sequencing of partial VP1 gene, Genetic and phylogenetic analysis and analysis of the data and writing the manuscript. Both authors read and approved the final manuscript for publication.

\section{Funding}

This study was funded by the Animal Health Research Institute, Egypt.

\section{Ethical considerations}

Ethical issues (including plagiarism, consent to publish, misconduct, data fabrication and/or falsification, double publication and/or submission, and redundancy) have been checked by the authors.

\section{REFERENCES}

Abdel-Alim GA, Awaad MH, and Saif YM (2003). Characterization of Egyptian field strains of infectious bursal disease virus. Avian Diseases, 47(4): 1452-1457. DOI: https://www.doi.org/10.1637/7032

Abou El-Fetouh MS, and Abdallah FM (2018). Genetic characterization of infectious bursal disease viruses isolated from the vaccinated broiler chicken flocks in Egypt during 2015-2016. Polish Journal of Veterinary Sciences, 21(3): 581-588. DOI: https://www.doi.org/10.24425/124293

Abd mawgod SA, Arafa AS, and Hussein HA (2014). Molecular genotyping of the infectious bursal disease virus (IBDV) isolated from Broiler Flocks in Egypt. International Journal of Veterinary Science and Medicine, 2(1): 46-52. DOI: https://www.doi.org/10.1016/j.ijvsm.2014.02.004

Adamu J, Owoade AA, Abdu PA, Kazeem HM, and Fatihu MY (2013). Characterization of field and vaccine infectious bursal disease viruses from Nigeria revealing possible virulence and regional markers in the VP2 minor hydrophilic peaks. Avian Pathology, 42(5): 420-433. DOI: https://www.doi.org/10.1080/03079457.2013.822055

Alkie TN, and Rautenschlein S (2016). Infectious bursal disease virus in poultry: current status and future prospects. Veterinary Medicine: Research and Reports, 7: 9-18. DOI: https://www.doi.org/10.2147/vmrr.s68905

Banda A, Villegas P, and El-Attrache J (2003). Molecular characterization of infectious bursal disease virus from commercial poultry in the United States and Latin America. 
Avian Diseases, 47(1): 87-95. DOI: https://www.doi.org/10.1637/00052086(2003)047[0087:mc oibd]2.0.co;2

Barathidasan R, Singh S, Kumar MA, Desingu P, Palanivelu M, Singh M, and Dhama K (2013). Recurrent outbreaks of infectious bursal disease (IBD) in a layer farm caused by very virulent IBD virus (vvIBDV) in India: pathology and molecular analysis. South Asian Journal of Expression Biology, 3: 200-206. Available at: http://sajeb.org/index.php/sajeb/article/view/17331

Bayliss CD, Spies U, Shaw K, Peters RW, Papageorgiou A, Muller H, and Boursnell, ME (1990). A comparison of the sequences of segment $\mathrm{A}$ of four infectious bursal disease virus strains and identification of a variable region in VP2. Journal of General Virology, 71(6): 1303-1312. DOI: https://www.doi.org/10.1099/0022-1317-71-6-1303

Boot $\mathrm{H} \mathrm{J}$, ter Huurne AA, Hoekman AJ, Peeters BP, and Gielkens AL (2000). Rescue of very virulent and mosaic infectious bursal disease virus from cloned cDNA: VP2 Is not the sole determinant of the very virulent phenotype. Journal of Virology, 74(15): 6701-6711. DOI: https://www.doi.org/10.1128/jvi.74.15.6701-6711.2000

Brandt M, Yao K, Liu M, Heckert RA, and Vakharia VN (2001). Molecular determinants of virulence, cell tropism, and pathogenic phenotype of infectious bursal disease virus. Journal of Virology, 75(24): 11974-11982. DOI: https://www.doi.org/10.1128/jvi.75.24.11974-11982.2001

Brown MD, Green P, and Skinner MA (1994). VP2 sequences of recent European 'very virulent isolates of infectious bursal disease virus are closely related to each other but are distinct from those of 'classical' strains. Journal of General Virology, $75(3)$ : $\quad 675-680 . \quad$ DOI: https://www.doi.org/10.1099/0022-1317-75-3-675

Cosgrove AS (1962). An apparently new disease of chickens: Avian nephrosis. Avian Diseases, 6(3): 385-389. DOI: https://www.doi.org/10.2307/1587909

Coulibaly F, Chevalier C, Gutsche I, Pous J, Navaza J, Bressanelli S, and Rey FA (2005). The birnavirus crystal structure reveals structural relationships among icosahedral viruses. Cell, 120(6): 761-772. DOI: https://www.doi.org/10.1016/j.cell.2005.01.009

Dobos P, Hill BJ, Hallett R, Kells DT, Bech H, and Teninges D (1979). Biophysical and biochemical characterization of five animal viruses with bisegmented double-stranded RNA genomes. Journal of Virology, 32(2): 593-605. DOI: https://www.doi.org/10.1128/jvi.32.2.593-605.1979

Durairaj V, Sellers HS, Linnemann EG, Icard AH, and Mundt E (2011). Investigation of the antigenic evolution of field isolates using the reverse genetics system of infectious bursal disease virus (IBDV). Archives of Virology, 156(10): 1717-1728. DOI: https://www.doi.org/10.1007/s00705-0111040-X

El-Bagoury G, Elsamaloty M, El-Habbaa A, and Haggag N (2018). Full VP2 sequence analysis of infectious bursal disease virus (IBDV) in broiler chicken in Egypt. Benha Veterinary Medical Journal, 35(2): 559-567. DOI:https://www.doi.org/10.21608/bvmj.2018.111776

El-Batrawi AM, and El-Kady MF (1990). Studies on severe outbreaks of infectious bursal disease 3-deternination of the critiealage of sysceptigilty in maternally immune chicks. Second Scientific Conference Egypt Veterinary poultry, pp. 264-269.

El-Sergany HA, Ann Moursi, Saber MS, and Mohamed MA (1974). A preliminary investigation on the occurrence of Gumboro disease in Egypt. Egypt Journal of Veterinary Science, 11: 185-208. Available at: https://ci.nii.ac.jp/naid/10006335446/

El-Sonusi A, Madbouly MM, Msis El-Bagoury GF, Abd El Bar NA, El-Batrawi A, and Reda IM (1994). Antigenic characterization of IBDV by the antigenic capture ELISA. (Ac-ELISA) using monoclonal antibodies. Beni Suef Veterinary Research, 4: 300-308.

Hagag N, Soliman MA, Arafa AS, Zanaty A, Erfan AM, and Hassan MK (2015). Genetic characteristics of infectious bursal disease virus in Egypt from 2012 to 2014. Assiut Veterinary Medicine Journal, 61(147): 43-51. Available at: http://www.aun.edu.eg/journal_files/437_J_8166.pdf

Hassan MK (2004). Very virulent infectious bursal disease virus in Egypt: Epidemiology, isolation and immunogenicity of classic vaccine. Veterinary Research Communications, 28(4): 347-356. DOI: https://www.doi.org/10.1023/b:verc.0000026657.29702.4e

Helal AM, El-Mahdy S, and Afify A (2012). Study the prevalence of variant IBD strains in some Egyptian chicken farms. New York Science Journal, 5(6): 8-11. DOI: http://www.sciencepub.net/newyork/ny0506/002_8801ny05 06_8_11.pdf

Hitchner SB (1970). Infectivity of infectious bursal disease virus for embryonating eggs. Poultry Science, 49(2): 511516.DOI: https://www.doi.org/10.3382/ps.0490511

Hussein AH, Aly AN, Sultan H, and Al-Safty M (2003). Transmissible viral pronventriculitis and stunting syndrome in broiler chicken in Egypt. 1. Isolation and characterized of variant infectious bursal disease virus. Veterinary Medical Journal, 51(3): 445-462. Available at: $\underline{\text { Link }}$

Jackwood DJ, and Sommer-Wagner SE (2011). Amino acids contributing to antigenic drift in the infectious bursal disease Birnavirus (IBDV). Virology, 409(1): 33-37. DOI: https://www.doi.org/10.1016/j.virol.2010.09.030

Jackwood DJ, Sreedevi B, LeFever LJ, and Sommer-Wagner S (2008). Studies on naturally occurring infectious bursal disease viruses suggest that a single amino acid substitution at position 253 in VP2 increases pathogenicity. Virology, 377(1):

110-116. DOI:https://www.doi.org/10.1016/j.virol.2008.04.018

Kasanga CJ, Yamaguchi T, Wambura PN, Maeda-Machang'u AD, Ohya K, and Fukushi H (2007). Molecular characterization of infectious bursal disease virus (IBDV): Diversity of very virulent IBDV in Tanzania. Archives of Virology, $\quad$ 152(4): 783-790. https://www.doi.org/10.1007/s00705-006-0898-5

Kumar S, Stecher G, and Tamura K (2016). MEGA7: Molecular evolutionary genetics analysis version 7.0 for bigger datasets. Molecular Biology and Evolution, 33(7): 18701874. DOI: https://www.doi.org/10.1093/molbev/msw054

Lejal N, Da Costa B, Delmas B, and Huet JC (2000). Role of ser652 and Lys-692 in the protease activity of infectious bursal disease virus VP4 and identification of its substrate cleavage 
sites. Journal of General Virology, 81(4): 983-992.DOI: https://www.doi.org/10.1099/0022-1317-81-4-983

Letzel T, Coulibaly F, Rey FA, Delmas B, Jagt E, van Loon AA MW, and Mundt E (2007). Molecular and structural bases for the antigenicity of $\mathrm{vp} 2$ of infectious bursal disease virus. Journal of Virology, 81(23): 12827-12835. DOI: https://www.doi.org/10.1128/jvi.01501-07

Lukert PD, and Saif YM (2003). Infectious bursal disease. In: Saif YM, Barnes HJ, Glisson JR, Fadly AM, McDougald LR, Swayne DE, editors. Diseases of poultry. Ames: Iowa State Press, pp. 161-179. Available at: Link

Metwally AM, Yousif AA, Shaheed IB, Mohammed WA, Samy AM, and Reda IM (2009). Re-emergence of very virulent IBDV in Egypt. International Journal of Virology, 5(1): 117. DOI: https://www.doi.org/10.3923/ijv.2009.1.17 Michel LO, and Jackwood DJ (2017). Classification of infectious bursal disease virus into genogroups. Archives of Virology, 162(12): $3661-3670$

DOI: https://www.doi.org/10.1007/s00705-017-3500-4

Mohamed MA, Elzanaty KES, Bakhit BM, and Safwat MM (2014). Genetic characterization of infectious bursal disease viruses associated with gumboro outbreaks in commercial broilers from asyut province, Egypt. ISRN Veterinary $\begin{array}{llll}\text { Science, } & \text { pp. } & 1-9 . & \text { DOI: }\end{array}$ https://www.doi.org/10.1155/2014/916412

Müller H, Islam Md R, and Raue R (2003). Research on infectious bursal disease - the past, the present and the future. Veterinary Microbiology, 97: 153-165. DOI: https://www.doi.org/10.1016/j.vetmic.2003.08.005

Mundt E, Beyer J, and Muller H (1995). Identification of a novel viral protein in infectious bursal disease virus-infected cells. Journal of General Virology, 76(2): 437-443. DOI: https://www.doi.org/10.1099/0022-1317-76-2-437

Murphy FA, Gibbs EPJ, Horzinek MC, and Studdert MJ (1999) Birnaviridae. In: Veterinary virology. Orlando: Academic Press, pp. 405-409. Available at: https://www.elsevier.com/books/veterinaryvirology/murphy/978-0-12-511340-3

Negash T, Gelaye E, Petersen H, Grummer B, and Rautenschlein $S$ (2012). Molecular evidence of very virulent infectious bursal disease viruses in chickens in Ethiopia. Avian Diseases, $\quad 56(3)$ : $605-610 . \quad$ DOI: https://www.doi.org/10.1637/10086-022012-resnote.1

Nwagbo IO, Shittu I, Nwosuh CI, Ezeifeka GO, Odibo FC, Michel LO, and Jackwood DJ (2016). Molecular characterization of field infectious bursal disease virus isolates from Nigeria. Veterinary World, 9(12): 1420-1428. DOI: https://www.doi.org/10.14202/vetworld.2016.1420$\underline{1428}$

Patel AK, Pandey VC, and Pal JK (2016). Evidence of genetic drift and reassortment in infectious bursal disease virus and emergence of outbreaks in poultry farms in India. Virus Disease, 27(2): 161-169. DOI: https://www.doi.org/10.1007/s13337-016-0306-z

Petkov D, Linnemann E, Kapczynski DR, and Sellers HS (2007). Full-length sequence analysis of four IBDV strains with different pathogenicities. Virus Genes, 34(3): 315-326. DOI: https://www.doi.org/10.1007/s11262-006-0021-8

Qi X, Gao H, Gao Y, Qin L, Wang Y, Gao L, and Wang X (2009). Naturally occurring mutations at residues 253 and 284 in VP2 contribute to the cell tropism and virulence of very virulent infectious bursal disease virus. Antiviral Research, 84(3): 225-233. DOI: https://www.doi.org/10.1016/j.antiviral.2009.09.006

Rautenschlein S, Kraemer C, Vanmarcke J, and Montiel E (2005). Protective efficacy of intermediate and intermediate plus infectious bursal disease virus (IBDV) vaccines against very virulent IBDV in commercial broilers. Avian Diseases, 49(2): 231-237. DOI: https://www.doi.org/10.1637/7310$\underline{112204 \mathrm{r}}$

Rauw F, Lambrecht B, and van den Berg T (2007). Pivotal role of ChIFN $\gamma$ in the pathogenesis and immunosuppression of infectious bursal disease. Avian Pathology, 36(5): 367-374. DOI: https://www.doi.org/10.1080/03079450701589159

Saif YM (1991). Immunosuppression induced by infectious bursal disease virus. Veterinary Immunology and Immunopathology, 30(1): 45-50. $\quad$ DOI: https://www.doi.org/10.1016/0165-2427(91)90007-y

Snyder DB (1990). Changes in the field status of infectious bursal disease virus. Avian Pathology, 19(3): 419-423. DOI: https://www.doi.org/10.1080/03079459008418695

Sultan H, Abdel-Razik AG, Shehata AA, Ibrahim M, Talaat S, Abo-Elkhair M, Bazid AE, Moharam IM, and Vahlenkamp $\mathrm{T}$ (2015). Characterization of infectious bronchitis viruses circulating in Egyptian chickens during 2012 and 2013. Journal of Veterinary Science and Medical Diagnosis, 4(5): 1-7. Link

Tomás G, Hernández M, Marandino A, Panzera Y, Maya L, Hernández D, and Pérez R (2012). Development and validation of a TaqMan-MGB real-time RT-PCR assay for simultaneous detection and characterization of infectious bursal disease virus. Journal of Virological Methods, 185(1): 101-107. DOI: https://www.doi.org/10.1016/j.jviromet.2012.06.012

van den Berg TP (2000). Acute infectious bursal disease in poultry: A review. Avian Pathology, 29(3): 175-194. DOI:https://www.doi.org/10.1080/03079450050045431

van den Berg TP, Morales D, Eterradossi N, Rivallan G, Toquin D, Raue R, Zierenberg K, Zhang MF, Zhu YP, Wang CQ et al. (2004). Assessment of genetic, antigenic and pathotypic criteria for the characterization of IBDV strains. Avian Pathology, 33(5): 470-476. DOI: https://www.doi.org/10.1080/03079450400003650

Zierenberg K, Nieper H, van den Berg TP, Ezeokoli CD, Voß M, and Müller H (2000). The VP2 variable region of African and German isolates of infectious bursal disease virus: Comparison with very virulent, "classical" virulent, and attenuated tissue culture-adapted strains. Archives of Virology, 145(1): 113-125. DOI: https://www.doi.org/10.1007/s007050050009 